\title{
Effect of Some Local Additives on the Chemical Constituent of Palm Oil
}

\author{
${ }^{1}$ EKOP, S A; ${ }^{1}$ ETUK, B A; *2EDDY, N O \\ ${ }^{1}$ Department of Chemistry, University of Uyo, Uyo, Nigeria \\ *22Department of Science Technology, Akwa Ibom State Polytechnic, Ikot Osurua, P. M. B. 1200, Ikot Ekpene, Akwa Ibom State
}

\begin{abstract}
Different quantities of palm oil from NIFOR plantation were mixed with some local additives (carrot, paw paw, lime and red dye). The oil samples were analysed for their moisture content, saponification value, iodine value, acid value and free fatty acid value before and after the addition of known and constant amount of the different additives. The values for the analysed parameters were subjected to statistical analysis and were compared with each other. The result of the analysis shows that the introduction of these additives significantly increases the saponification value, iodine value, acid value, moisture content and free fatty acid value of the palm oil. Also, the quality of the red palm oil (which is a functions of these parameters) was adversely affected @JASEM
\end{abstract}

In recent time, production and consumption of palm oil have increased exponentially. Palm oil is exported to more than ninety countries. In terms of production, it is second only to soya-bean oil.

Palm oil is perhaps the most widely used and applied plant oil. The uses of palm oil in the homes and industries have been acknowledged (Lee, 1984; Offem et al, 2003; Shaw, 1980; Woollatt, 1985). Red palm oil (RPO), besides providing calorie density to the diet, is also the richest natural source of $\beta$ carotene, a precursor of vitamin A and an antioxidant that destroys singlet oxygen and free radicals (Rukmini, 1994). According to May (1994), crude palm oil is the richest natural plant source of carotenoids in terms of retinol (provitamin A) equivalent. Elena and Parker (1994) have also stated that palm oil serves as antioxidant because it contains vitamin E, and also contained about $45 \%$ tocopherols and $55 \%$ tocotrienols.

Rao (1994) has also reported that India is experiencing a shortage of edible oils that may increase in years to come and that to meet this challenge, palm oil is being considered as a potential new source of oil owing to the high productivity of the oil palm. Besides importing palm oil for the present, indigenous production by cultivating the oil palm has been initiated as a long-term measure. Hussein (1994) also reported that Edible oils and fats are important sources of food energy in North Africa and West Asia. Because of the high cost of animal fats and increased awareness of potential harm from their excessive consumption, the rise of vegetable oils is increasing

Arising from the above uses and application of palm oil, it becomes necessary to undertake a study on factors that affects the quality of palm oil. Various adulteration reports have been published in different websites and literature for instance, Akunyili (2004) stated that even $1 \%$ changes in the quality of Nigerian palm oil is not recommended. In most cases, the producers usually do the adulteration in order to increase the quantity of the oil that is produced. Unfortunately, most adulteration practice is normally done without considering its effect on the quality of palm oil. The present study is aimed at considering the effect of carrot; paw paw, lime, and red dye on the quality of palm oil. These additives are normally utilized by most commercial dealers on palm oil as a method of increasing the quantity of palm oil.

\section{MATERIALS AND METHODS}

Pure sample of palm oil was obtained from NIFOR (Nigerian Institute for Oil Palm Research) in Abak, Akwa Ibom State, Nigeria. There was no need for further purification of the oil since they were already extracted and decanted in a bottle. The oil was divided into five clean plastic containers, to each bottle measured quantity of the wlocal additives were added. Bottle A contained a pure sample of oil (PO); bottle B contained $10 \mathrm{ml}$ of pure sample of oil and $1 \mathrm{~g}$ of carrot (POC); bottle $\mathrm{C}$ contained $10 \mathrm{ml}$ of pure sample of oil and $1 \mathrm{~g}$ of ripe pawpaw (POP), bottle D contained $10 \mathrm{ml}$ of pure sample of oil and $1 \mathrm{~g}$ of lime (POL), while bottle E contained pure sample of oil and $0.5 \mathrm{~g}$ of dye (POD). The samples were heated for 20 minutes in a water bath maintained at $60^{\circ} \mathrm{C}$. The reagents used in the work were analar grade reagent obtained from the University of Uyo laboratory.

Determination of iodine value of palm oil: $0.5 \mathrm{~g}$ each of the oil samples/oil and additives mixture was dissolved in a few quantities $(100 \mathrm{ml})$ of chloroform contained in a $500 \mathrm{~cm}^{3}$ conical flask. $25 \mathrm{ml}$ of Hanus solution was added into each flask, corked and allowed to stand for 30minutes in the dark. A blank 
test was carried out without the samples using exactly the same quantity of chloroform and hanus solution, stoppered, kept for the same length of time.

When the reaction was completed, $15 \mathrm{~cm}^{3}$ of $10 \%$ potassium iodide solution and $10 \mathrm{ml}$ of distilled water was added to each flask mixed by gentle shaking. The content of the flask was titrated with $0.1 \mathrm{~N}$ $\mathrm{Na}_{2} \mathrm{~S}_{2} \mathrm{O}_{3}$ to pale yellow before the addition of $2 \mathrm{ml}$ of starch indicator. The titration continued until the blue-black colour was completely discharged. The iodine value was calculated from the equation, $1.26(\mathrm{a}-\mathrm{b}) / \mathrm{w}$ $1 \mathrm{~cm}^{3}$ of $0.1 \mathrm{~N} \mathrm{Na}_{2} \mathrm{~S}_{2} \mathrm{O}_{3} \equiv 0.01269 \mathrm{~g}$ of iodine

where, $\mathrm{w}=$ weight of the sample., $\mathrm{b}=$ volume of $0.1 \mathrm{~N} \mathrm{Na}_{2} \mathrm{~S}_{2} \mathrm{O}_{3}$ for the sample and $\mathrm{a}=$ volume of $0.1 \mathrm{~N}$ $\mathrm{Na}_{2} \mathrm{~S}_{2} \mathrm{O}_{3}$ for the blank

Determination of peroxide value of palm oil: The method reported by A.O.A.C (1975) was used. $2 \mathrm{~g}$ each of the oil samples were respectively weighed into different conical flasks and $15 \mathrm{ml}$ of the mixture of $\mathrm{CH}_{3} \mathrm{COOH}-\mathrm{CHCl}_{3}$ in the ratio of $3: 2$ respectively was added to the oil sample. $0.5 \mathrm{ml}$ of saturated potassium iodide was added to each conical flask and allowed to stand for 5minutes, thereafter, $15 \mathrm{ml}$ of distilled water was added and filtrated with $0.1 \mathrm{~N}$ $\mathrm{Na}_{2} \mathrm{~S}_{2} \mathrm{O}_{3}$ until a yellowish colour almost disappeared, then $0.5 \mathrm{ml}$ of starch was added and the titration continued to a colourless end-point. The peroxide value was calculated from the equation, $\mathrm{Pv}=1000\left(\mathrm{v}_{2}-\right.$ $\left.\mathrm{v}_{1}\right) \mathrm{T} / \mathrm{m}$, where $\mathrm{M}=$ mass of oil taken $(2 \mathrm{~g}), \mathrm{V}_{2}=$ volume of $0.1 \mathrm{~N} \mathrm{Na} \mathrm{S}_{2} \mathrm{O}_{3}, \mathrm{~V}_{1}=$ volume of $0.1 \mathrm{~N}$ blank and $\mathrm{T}=$ normality of $\mathrm{Na}_{2} \mathrm{~S}_{2} \mathrm{O}_{3}(0.1 \mathrm{~N})$.

Determination of saponification value of palm oil: $2 \mathrm{~g}$ of each of the oil sample were respectively weighed into the different conical flasks and $25 \mathrm{ml}$ of ethanolic potash was added. To another flask was added the same quality of the ethanolic potash but omitting the oil sample, this was used blank. All the flasks were boiled in a water bath for 30minutes with frequent shaking. Two drops of phenolphthalein indicator was added to each flask and titrated with $0.5 \mathrm{M} \mathrm{HCl}$ with vigorous shaking, without delay to get the end point and the saponification value was calculated from the expression, $1 \mathrm{~cm}^{3}$ of $0.5 \mathrm{M}$ of $\mathrm{HCl}$ $\equiv 0.02805 \mathrm{~g} \mathrm{KOH}$

Determination of free fatty acid value of palm oil: $25 \mathrm{ml}$ of ethanol was added to $1.5 \mathrm{~g}$ of each oil sample contained in the different conical flasks. The mixture was brought to boil in a water bath then cooled. Two drops of phenolphthalein indicator was added to the solution. $0.1 \mathrm{M} \mathrm{NaoH}$ was used to titrate the mixture with constant shaking for proper mixing and the FFA was calculated from the expression, $\% \mathrm{FFA}=(\mathrm{V} \mathrm{x}$ EKOP, $S A$; ETUK, B A; EDDY, NO
$0.0282 \times 100) /($ Weight of the sample), where $\mathrm{V}=$ sample titre, $\mathrm{w}=$ weight of the sample, $1 \mathrm{~cm}^{3}$ of $0.1 \mathrm{M}$ $\mathrm{NaoH}$ contains 0.0282 of oleic acid.

Determination of acid value of palm oil: $2 \mathrm{~g}$ each of the different oil samples were weighed and were added to $25 \mathrm{~cm}^{3}$ of $\mathrm{ccl}_{4}$ in different conical flasks. Two drops of phenolphthalein was then added to the mixture. A similar titration was performed without the sample to determine the blank and titration was carried out with $0.1 \mathrm{~N}$ alcoholic potash until the colour change occurred in the different conical flasks. The acid value was calculated from the equation, acid value $=($ sample titre - blank $) 0.1 \times 56.1 / \mathrm{w}$. Where $\mathrm{W}$ $=$ weight of sample

\section{RESULT AND DISCUSSION}

The result of the mean concentrations of moisture, iodine value, acid value, peroxide value and free fatty acid value of the palm oil and their respective standard deviation after it was mixed with the different additives were as shown in Table 1. The moisture content of the palm oil (PO) was found to be $0.23 \%$. When palm oil (PO) was mixed with carrot, paw paw, lime and dye, the moisture content of the POC, POP, POL and POD were increased to $0.79 \%$, $10.40 \%, 0.48 \%$ and $0.43 \%$ respectively. There was a significant difference between the moisture content of PO and POC $(\mathrm{t}=96.99, \mathrm{n}=3, \alpha=0.05)$; PO \& POP $(\mathrm{t}=115.70, \mathrm{n}=3, \alpha=0.05) ; \mathrm{PO}$ and $\operatorname{POL}(\mathrm{t}=$ 43.30, $\mathrm{n}=3, \alpha=0.05)$ and between PO and POD $(\mathrm{t}=$ $6.10, \mathrm{n}=3, \alpha=0.05)$. The acid value of Po was $10.04 \mathrm{mg} / \mathrm{g}$ of oil while the acid values for PO, POL, POP and POD were 10.09, 10.37, 10.66 and 16.50 respectively. There was a significant difference between the acid value of $\mathrm{PO}$ and the acid value of POL, POC, POP and POD $(\mathrm{P} \leq 0.05)$

The saponification value of the PO was $126.22 \mathrm{mgKOH} / \mathrm{g}$. When the carrot, paw paw, lime and dye were mixed with different samples of the oil, the saponification value was increased to 126.88 $\mathrm{mgKOH} / \mathrm{g}, 134.64 \mathrm{mgKOH} / \mathrm{g}, 131.86 \mathrm{mgKOH} / \mathrm{g}$ and $141.62 \mathrm{mgKOH} / \mathrm{g}$ respectively. There was a significant difference between the saponification value of $\mathrm{PO}$ and $\mathrm{POL} ; \mathrm{PO}$ and $\mathrm{POC} ; \mathrm{PO}$ and $\mathrm{POP}$; $\mathrm{PO}$ and $\mathrm{POD}(\mathrm{P} \leq 0.05)$. The iodine value of the $\mathrm{PO}$ was $56.34 \mathrm{I}_{2} / 100 \mathrm{~g}$. When different samples of PO were respectively mixed with lime, carrot, paw-paw, lime and red dye, the iodine values were $61.16 \mathrm{I}_{2} / 100 \mathrm{~g}, 54.56 \mathrm{I}_{2} / 100 \mathrm{~g}, 55.07 \mathrm{I}_{2} / 100 \mathrm{~g}$, and 56.34 $\mathrm{I}_{2} / 100 \mathrm{~g}$ respectively. There was no significant difference between the iodine values of PO \& POL $(\mathrm{P} \leq$ 0.05). However, there was a significant difference between the iodine value of PO \& POC ; $\mathrm{PO}$ and POP and between PO \& POD $(\mathrm{P} \leq 0.05)$. 
Full-text Available Online at www.bioline.org.br/ja

Vol. 11 (1) 85 - 89

Table 1: Chemical composition of palm oil and palm oil-additives mixture

\begin{tabular}{llllll}
\hline Chemical constants & PO & POC & POL & POP & POD \\
\hline Moisture content $(\%)$ & 0.23 & 0.79 & 0.48 & 10.40 & 0.43 \\
\% free fatty acid & 7.32 & 7.52 & 7.14 & 7.14 & 8.08 \\
Peroxide value $(\mathrm{Meq} / \mathrm{kg})$ & 2.0 & 12.00 & 12.00 & 16.00 & 12.00 \\
Acid value $(\mathrm{mg} / \mathrm{g}$ of oil) & 10.04 & 10.37 & 10.09 & 10.66 & 16.50 \\
Iodine value $\left(\mathrm{I}_{2} / \mathrm{l}\right.$ (00) of oil) & 56.34 & 54.56 & 61.16 & 55.07 & 56.34 \\
Saponification value $(\mathrm{mg} / \mathrm{gKOH})$ & 126.22 & 134.64 & 126.88 & 131.86 & 141.6 \\
\hline
\end{tabular}

The peroxide value of the PO was $20.00 \mathrm{Meq} / \mathrm{kg}$. When different samples of the PO were respectively mixed with lime, carrot, paw-paw and red dye, the peroxide values were reduced to $12.00 \mathrm{Meq} / \mathrm{kg}$, $12.00 \mathrm{Meq} / \mathrm{kg}, \quad 16.00 \mathrm{Meq} / \mathrm{kg}$ and $12.00 \mathrm{Meq} / \mathrm{kg}$ respectively. There was no significant difference between the peroxide value of PO \& POL ; PO \& POC; PO \& POP and between PO and POD (P $\leq$ 0.05). The free fatty acid (FFA) content of the PO was $7.33 \%$. When the PO was mixed with lime, carrot, paw-paw and red dye respectively, the FFA were $7.13 \%, 7.52 \%, 7.14 \%$ and $8.08 \%$ respectively. There was a significant difference between the FFA of PO \& POC $(\mathrm{P} \leq 0.05)$ and between the FFA of PO and $\mathrm{POD}(\mathrm{P} \leq 0.05)$.

The quality of palm oil can best be assessed by analyzing the oil samples for its chemical constants. A shift in the value of any of these chemical constants from the expected range can be used as an index of adulteration or deterioration of the oil quality. (Woodlatt, 1985). This constants are expressed in values which can be adapted to assed the quality of the oil. The change in any of these parameters during the storage or handling of palm oil signifies that there is a change in the quality of palm oil.

Etuk (1998) stated that because fat and oil have constant fatty acid composition within the limit of biological variation, saponification value is a unique and reliable means of characterizing fat and oil. S.V depends on the growing conditions of the oil bearing plants and the method of extraction. The saponification value of oil also increases as the molecular weight and chain length of the oil decreases. Thus the addition of the additives tends to lower the saponification values of the palm oil. The significant increase in the saponification value of the POL, POC, POP, POD may be due to the effect of these additives on the molecular weight and chain length of the oil.
According to Scott (1956), the moisture content of any food materials could be used as an index of stability and susceptibility to fungal infection. Available literature confirms that plant and animal materials contain moisture in significant proportion (Aurand and Wood, 1976; Eddy, 2004a; James, 1984; Lee, 1984). Therefore the significant increase in the moisture content of PO when carrot, paw-paw, lime and dye were added to the oil can be attributed to the combination of the inherent moisture content of the plant. The increase in moisture content was much significant when the palm oil was mixed with pawpaw where there was a 4421.739 percentage increase in moisture content. According to Umoh (1998)., the moisture content of paw-paw ranges from 87.29 to $91.02 \%$ which explain the alarming increase in moisture content of the POP.

Acid value is defined by Woodlat (1985) as the number of $\mathrm{mg}$ of $\mathrm{KOH}$ requires to neutralised $1 \mathrm{~g}$ of fatty acid in an oil. According to Divine and Williams (1987), the acid value of oil is a measure of the quality of oil. During the study, the significant difference between the acid value of PO \& POC, PO $\&$ POP and PO \& POD shows that carrot, paw-paw and dye can significantly increase the acid value of oil. This might be due to the increase in the moisture content of the oil as a result of the addition of the carrot, paw-paw and dye to the palm oil. Woodlat (1985) has reported that an increase in the acid value of oil is an indication of the onset of rancidity. $\mathrm{He}$ also stated that rancidity can be accelerated by moisture, air and presence of some metals hence the increase in the moisture content of the oil during the period of observation can be attributed to the introduction of moisture into the oil, the increase penetration of oxygen into the oil molecule (aided by the introduction of the paw paw, carrot and dye) and the introduction of some metals into the oil molecule. Heavy metals have been reportedly found in some plant materials. Dara (1993) has reported significant concentration of some heavy metals in some plant food materials and the concentrations of some of these heavy metals were above the permissible limit. 
Although the concentration of heavy metals such as copper in the carrot, paw paw and the dye were not measure during the study, Available literature show that the entrance route for the heavy metals into the plant tissue could involved absorption through the soil, manure and other environmental factors. Eddy (2004c) also stated that when once these heavy metals are introduced into the plant tissue, the metals undergo biomagnification process therefore the presence of heavy metals such as copper in the tissues of the plants used as additives in this work might have contributed to the increased acid value of the PO.

The free fatty acid (FFA) of the POD and POC were significantly higher than the FFA of PO while that of POP and POL were lower than the FFA of PO. The implication is that lime and paw paw does not increase the FFA of $\mathrm{PO}$ while dye and carrot increases the FFA of PO. FFA represents the fatty acid molecules that have been free by lipase oxidation. The freedom of the fatty acid molecule in the PO could therefore be influence by the addition of red dye and paw-paw. The increase in the FFA of the POC and POD might be due to the increase lipase activity as the moisture content of the oil increases while the decrease in the FFA of POP and POL might be due to the present of antioxidant in the paw paw and lime fruit (Umoh, 1998: Eddy, 2004b).

Iodine value is a chemical parameter that characterized oil based on the degree of unsaturation. Swern (1979) and Etuk (1998) has reported that the higher the degree of unsaturation in an oil sample, the higher the iodine value of that oil. It therefore follows that any substances, which can increase the degree of unsaturation in an oil sample, will raised the iodine value of the oil. The non-significant difference between the iodine value of the mixed oil and pure PO therefore signify that these additives do not exert a significant effect on the degree of unsaturation of the oil or the iodine value. The present of antioxidant in the oil or the additives could also be responsible for the insignificant difference between the iodine values of the samples when additives were added.

The peroxide values of POP, POL, POD and POC were found to be lower than the peroxide value of PO. The insignificant difference between the peroxide values of the samples suggests that these additives do not significantly increase the peroxide value of PO. Peroxide value is a measure of the degree of oxidation of the oil hence low peroxide value indicates a decreasing rate of oxidation. The low peroxide values exhibited by the samples might have been due to the decrease in the rate of oxidation. The presence of antioxidants in these plants tissues EKOP, $S$ A; ETUK, B A; EDDY, NO has been confirmed for example Umoh (1998) has reported the presence of vitamin $\mathrm{C}$, citrus acids and flavanoids in some fruits. These antioxidants act as scavenger of damaging oxygen free radicals for example, vitamin $\mathrm{C}$ prevent the loss of colour and flavour by reacting with unwanted oxygen (Adelakin, 2004). The role of citric acid as a metal scavenger has also been reported by Woodlat (1985)

Conclusion: From the study the additives considered increase the moisture content, saponification value, iodine value and acid value of palm oil. This implies that these additives have the potential of adulterating palm oil. Therefore since the addition of the additives to the palm oil before marketing is usually aimed at increasing the market value and not the quality value of palm oil.

In Nigeria significant attempt has not been made toward the control of the quality of palm oil offered for sale. This draws a line between quality and quantity of palm oil. It is therefore recommended that the use of additives in increasing the quantity of palm oil should be strongly discouraged perhaps through proper legislation.

Acknowledgement: The authors of this article are grateful to Mrs. Edikan Nnabuk Eddy of the national Office for Technology Acquisition and Promotion for typing the work and to the staff of University of Uyo central laboratory for providing the apparatus and materials used in the research.

\section{REFERENCES}

A. O. A. C. (1984). Official Methods of Analysis, Association of Official 1 Analytical Chemists. $12^{\text {th }}$ ed. William Hormitz.

Adelakin, E A (2004). Natural antioxidant. The chemistry of the importance of fruits and vegetables in Human diet. Proceedings of the $24^{\mathrm{Th}}$ Annual conference of the chemical society of Nigeria. Benin, Nigeria

Crombie, W M ; Hardman, E E (1958). Fat metabolism in the west African oil palm. Part 3: Fatty acids formation in the maturing exocarp Journal of experimental otany 4: 247-253.

Divine, J ; Williams, P (1961). The chemistry and technology of edible oil and fat..London: First edition. Pergamon press. London.

Earp, D A ; Newall, W (1976). International development in palm oil. The incorporated society of pantens, Kuala, Malaysia. 
Eddy, N O (2004a). The effect of processing on the chemical composition of some Nigerian Food crops. M.Sc Thesis, University of Uyo.

Eddy, N O (2004b). Physiochemical parameters of water and heavy metals contents of sediments, water and fishes from Qua Iboe River estuary. M.Sc thesis. Michael Okpara University of Agriculture, Umudike.

Eddy, N O (2004c). Toxicity of heavy metals. A seminar paper presented to the Department of Chemistry, University of Uyo.

Ekpa, O D ; Akpanabiatu, M ; Mauro, A ; Renzo, R (2000). Varietal differences and polymorphism in palm oil: A case study of palm oils blended with coconut oil. Global J. of pure \& applied science. $2: 277-282$.

Elena, A S ; Packer, L (1994). Antioxidant and biological activities of palm oil vitamin E. In Food and Nutrition Bulletin. Vol. 15 (1993/1994), Number 2, June 1994. United nation University press,

Etuk, E (1998). Lipid Biochemistry. Etihew Pub. Uyo, Nigeria 1998

Finar, L (2000). Organic Chemistry. The English language book society and Longman group. $6^{\text {th }}$ ed. London.

Hayes, K. C. ; Khosla, P (1994). Cholesterolaemic effect of saturated fatty acids of palm oil. In Food and Nutrition Bulletin. Vol. 15 (1993/1994),

Number 2, June 1994. United nation University press.

Hin, Y C. (1994). Nutritional aspect of palm oil. In Food and Nutrition Bulletin. Vol. 15 (1993/1994), Number 2, June 1994. United nation University press.

Hiroyuki, M ; Kaneda, T (1994). Food uses of palm oil in Japan. In Food and Nutrition Bulletin. Vol. 15 (1993/1994), Number 2, June 1994. United nation University press.

Hussien, M A (1994). Palm oil use in North Africa and West Asia. In Food and Nutrition Bulletin. Vol. 15 (1993/1994), Number 2, June 1994. United nation University press.
IUPAC (1987). International union of pure and applied chemist. Standard methods of fat and oil analysis.

James, C S (1984). Analytical chemistry of food. Blackie academic and Professional. London. 36 76

Lee, R A (1983). Basic food chemistry. 2nd edition. The AVI Publishing Company,Inc. Westport, Connecticut 1983

May, Y C (1994). Palm oil carotenoids. In Food and Nutrition Bulletin. Vol. 15 (1993/1994), Number 2, June 1994. United nation University press.

Mottram, R F (1979). Human Nutrition. Edward Arnold Pub. London 1979

Offem, S O; Mona, E E ; Onuchukwu, A ; Onouha, $\mathrm{N}$ (2003). Analytical indices for the identification of adulterated vegetables oil-palm kernel. J. of chem. Soc. Nigeria 28: 87-92

Rao, N S B (1994). Palm oil use and compatibility in India. In Food and Nutrition Bulletin. Vol. 15 (1993/1994), Number 2, June 1994. United nation University press.

Rukmini, C (1994). Red palm oil to combat vitamin A deficiency in developing countries. In Food and Nutrition Bulletin. Vol. 15 (1993/1994), Number 2, June 1994. United nation University press, 1994

Scott, W J (1980). Water relations of food spoilage microorganism. Adv. Food Res. 7: 84-89.

Soni, P I (1981). Textbook of organic chemistry. A Mordern approach. Suttan Chand and sons. New Delhi.

Swern, D (1979). Bailey's industrial oil and fat products. $2^{\text {nd }}$ ed. John Willey and Sons. London .

Umoh, I B (1998). Commonly used fruits in Nigeria. In Nutritional quality of plants food. Osagie, A. U. and Ekpa, O. U. eds. Post Harvest research unit. Benin, Nigeria.

Wollat, E E (1985). The manufacture of soap, other detergents and glycerine. $2^{\mathrm{Nd}}$ Ed. Ellis Harwood Pub. England. 